\title{
Diclofenac-induced hepatotoxicity
}

\author{
D. Schapira, L. Bassan, A.M. Nahir and Y. Scharf \\ The B. Shine Department of Rheumatology and the Department of Pathology, Rambam Medical Center, and \\ Faculty of Medicine, Technion-Israel Institute of Technology, Haifa, Israel.
}

\begin{abstract}
Summary: Two patients developed clinical, biochemical and histopathological signs of a liver hypersensitivity reaction following treatment with diclofenac. Hepatic side effects of this drug are very rare. The relevant literature is reviewed.
\end{abstract}

\section{Introduction}

Clinical and laboratory side effects of non-steroidal anti-inflammatory drugs are well known. Hepatotoxicity is one of the rare side effects of aspirin (Seaman et al., 1974), indomethacin (Kelsey \& Scharyj, 1967), naproxen (Victorino et al., 1980), phenylbutazone (Benjamin et al., 1981), sulindac (Whittaker et al., 1982) and other drugs (Zimmerman, 1981).

Diclofenac sodium (Voltaren) is a potent and widely used non-steroidal anti-inflammatory and analgesic compound. It is classified among the most powerful drugs of this kind, while being one of the best tolerated (Brunner \& Krupp, 1976). Diclofenac and its metabolites are excreted in both urine and bile. Experiments showed that the main route of drug elimination is different in various species, renal excretion being the most important in man and rhesus monkey and biliary excretion the most important in rat and dog. The lack of enterohepatic recycling in man probably accounts for the reduced gastrointestinal toxicity of this drug (Menasse et al., 1978). Hepatic side effects are very rare. We report two patients who developed acute hepatotoxicity shortly after the initiation of treatment with diclofenac.

\section{Case reports}

Case 1

A 68 year old woman had diffuse joint pains and recurrent knee effusions. Treatment with diclofenac $100 \mathrm{mg} /$ day brought relief. However, 2 weeks later, low grade fever and lassitude appeared together with pathological values of bilirubin, alkaline phosphatase

Correspondence: D. Schapira, M.D., Dept. of Rheumatology, Rambam Medical Center, Haifa 35254, Israel.

Accepted: 2 July 1985 and transaminase. The drug was withdrawn and the pathological, clinical and laboratory findings disappeared. Other non-steroidal anti-inflammatory drugs failed to improve the joint pains and diclofenac was reintroduced. A week later fever and lassitude returned together with a diffuse maculopapular skin rash, clinical jaundice and abnormal liver function: bilirubin $88.9 \mu \mathrm{mol} / 1$ (normal <20.0) $(54.7 \mu \mathrm{mol} / 1$ direct), aspartate transaminase $90 \mathrm{IU} / 1$ (normal 5-42), alkaline phosphatase 274 IU/1 (normal 20-85). The erythrocyte sedimentation rate was $30 \mathrm{~mm} / \mathrm{h}$, the white cell count $15 \times 10^{9} / 1 \quad(42 \%$ eosinophils $)$. Hepatitis B surface antigen $\left(\mathrm{HB}_{\mathrm{s}} \mathrm{Ag}\right)$, antismooth muscle and antimitochondrial antibodies were absent. There was a mild elevation of the IgG, the serum levels of IgM and IgA were normal. Immunological tests for collagen diseases and serological tests for various bacterial or viral agents were negative.

Scintigraphy revealed no hepatomegaly. The microscopical examination of the skin biopsy revealed normal epidermis. In the upper dermis a mixed infiltrate around the small blood vessels was seen (Figure 1). The infiltrate consisted mainly of lymphocytes but a few polymorphonuclear cells were also present. The bone marrow biopsy showed a few granulomas without necrosis consisting of Langhan's type giant cells, epitheloid cells and many eosinophils (Figure 2).

Permission for liver needle biopsy was not obtained. The drug was discontinued once more. The clinical jaundice and the skin rash rapidly disappeared. Both liver function and blood count returned to normal within 2 months.

\section{Case 2}

A 70 year old woman was admitted for recurrent inflammation of the wrists, the knees and the finger joints. The erythrocyte sedimentation rate was $47 \mathrm{~mm} /$ 


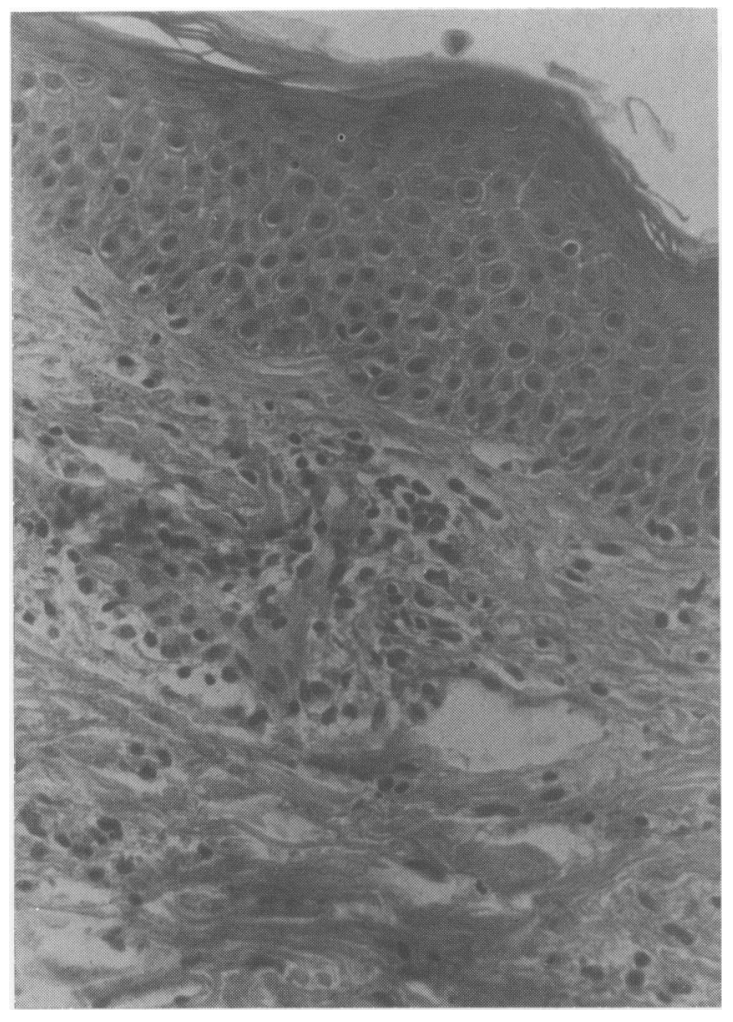

Figure 1 Case 1. Vasculitis in upper dermis (H \& $\mathrm{E} \times 125)$.

hour, the complete blood count, liver function tests, blood proteins and protein electrophoresis were nor$\mathrm{mal}$, and rheumatoid and antinuclear factor were absent. Calcium pyrophosphate deposition disease with diffuse pseudogout attacks was diagnosed and treatment with diclofenac, $150 \mathrm{mg} / \mathrm{d}$ was initiated. Five days later a diffuse maculopapular skin rash and pruritus appeared and icteric sclerae were noticed.

The stools were acholic and the urine was dark. The bilirubin was $82 \mu \mathrm{mol} / 1 \quad(44.5 \mu \mathrm{mol} / 1$ direct $)$, the aspartate transaminase $100 \mathrm{IU} / \mathrm{l}$, the alkaline phosphatase $173 \mathrm{IU} / 1$ and the lactic dehydrogenase 626 IU/1 (normal 115-480). The white blood cells were $8.8 \times 10^{9} / 1$ (6\% eosinophils). The liver technetium scan was normal and abdominal echography failed to disclose extrahepatic biliary obstruction. $\mathrm{HB}_{\mathrm{s}} \mathrm{Ag}$, antimitochondrial, antismooth muscle and antiparietal cell antibodies were absent.

Liver needle biopsy revealed slight fatty metamorphosis of the liver cells. There was centrilobular confluent hepatocyte loss (Figure 3a) associated with mixed lymphocytic and polymorphonuclear infiltrate. The hepatocytes showed ballooning and there were a

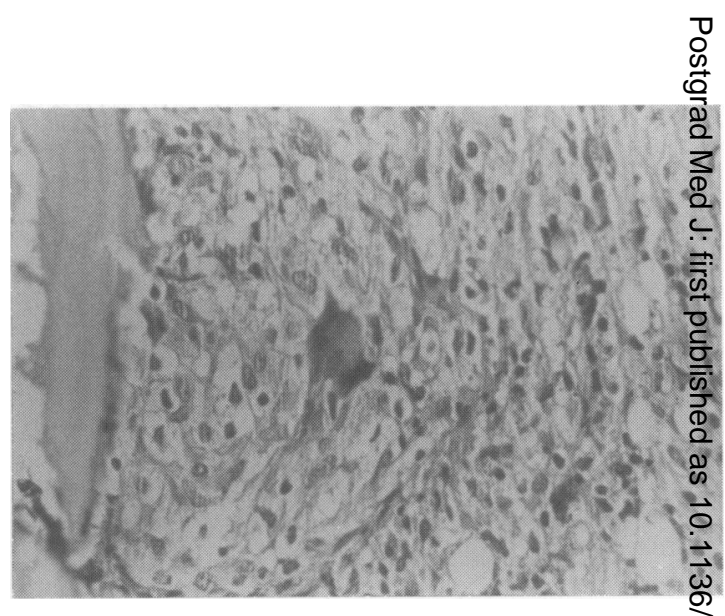

Figure 2 Case 1. Bone marrow granuloma (H $\mathrm{E} \times 500)$.

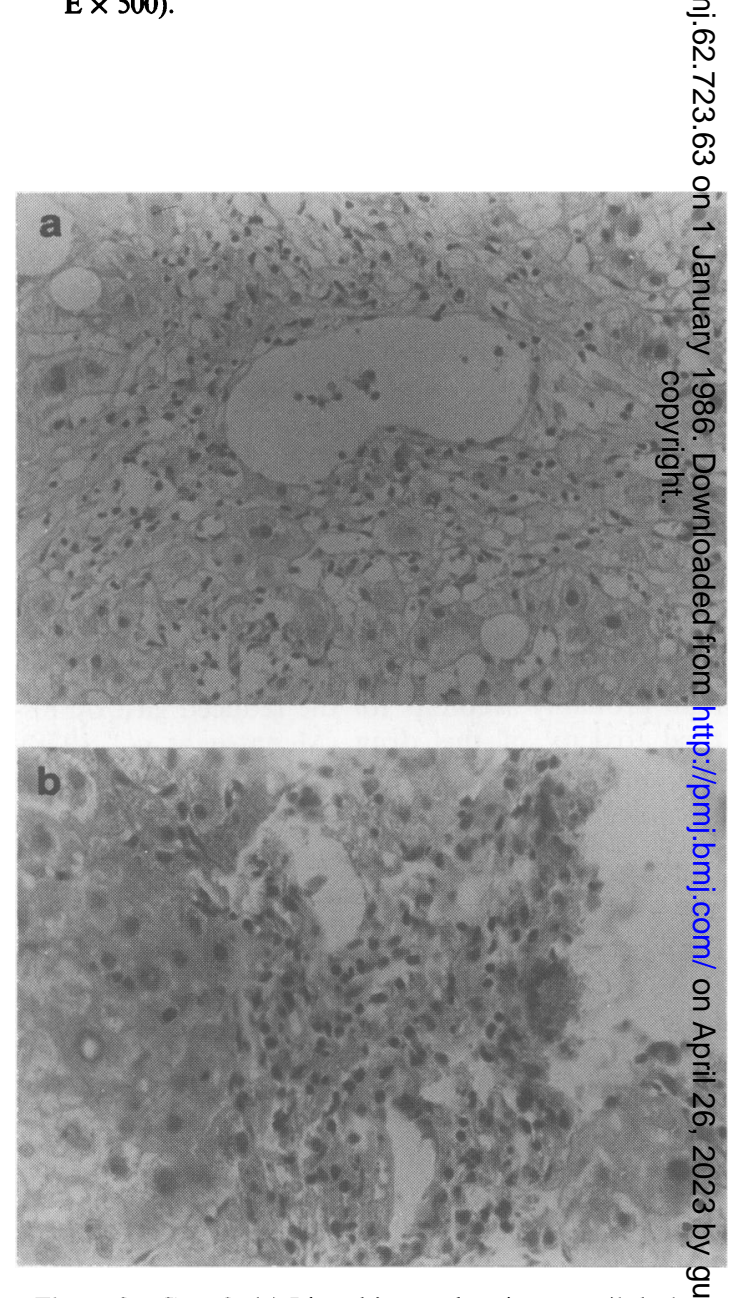

Figure 3 Case 2. (a) Liver biopsy showing centrilobula confluent hepatocyte loss (H \& E $\times 325)$. (b) Portaf tract with giant cell Langhans' type surrounded by mononuclear infiltration (H \& E $\times$ 325). 
few acidophilic bodies. A single portal non-caseating granuloma was found (Figure 3b) with one Langhan's type giant cell and mononuclear infiltration around it. No microorganisms were demonstrated.

The stains for iron and $\mathrm{HB}_{\mathrm{s}} \mathrm{Ag}$ (Shikata technique) were negative. Drug-induced hepatitis was diagnosed. The withdrawal of diclofenac brought a gradual clinical and laboratory remission within 1 month.

\section{Discussion}

Minor abnormalities of liver function (Shiokawa et al., 1972; Nasution, 1976; Trang et al., 1976; Ciccolunghi et al., 1978, 1979; Ciucci, 1979; McMahon \& Cash, 1979), as well as isolated cases of jaundice (Dunk et al., 1982; Babany et al., 1983) have been reported in patients treated with diclofenac. Concurrent therapy with other drugs or previous liver and biliary tract disease in most of the cases made the diagnosis of

\section{References}

BABANY, G., PESSAYRE, D. \& BENHAMOU, J.P. (1983). Hepatite on diclofenac. Gastroenterology and Clinical Biology, 7, 316.

BENJAMIN, S.B., ISHAK, K.G., ZIMMERMAN, H.J. \& GRUSHKA, A. (1981). Phenylbutazone liver injury: a clinicalpathological survey of 23 cases and review of the literature. Hepatology, 1, 255.

BRUNNER, H. \& KRUPP, P. (1976). Highlights of the pharmacology and pharmacokinetics of diclofenac (Voltaren). In Voltaren Symposium. p.9-16. Hans Huber: Bern, Stuttgart, Vienna.

CICCOLUNGHI, S.M., CHANDRI, H.A., SCHUBIGER, B.J. \& REDROP, R. (1978). Report on long term tolerability study of up to two years with diclofenac sodium (Voltaren). Scandinavian Journal of Rheumatology, Suppl. 22, 86.

CICCOLUNGHI, S.N., CHANDRI, H.A. \& SCHUBIGER, B.J. (1979). The value and results of long term studies with diclofenac sodium (Voltaren). Rheumatology and $R e$ habilitation, Suppl. 2, 100.

CIUCCI, A.G. (1979). A review of spontaneously reported adverse drug reaction with diclofenac sodium (Voltaren). Rheumatology and Rehabilitation, Suppl. 2, 116.

DUNK, A.A., WALT, R.P., JENKINS, W.J. \& SHERLOCK, S.S. (1982). Diclofenac hepatitis. British Medical Journal, 284, 1605.

KELSEY, W.M. \& SCHARYJ, M. (1967). Fatal hepatitis, probably due to indomethacin. Journal of the American Medical Association, 199, 586.

MCMAHON, M.F. \& CASH, H.C. (1979). An open assessment of the efficacy and tolerability of diclofenac sodium (Voltarol) in patients with rheumatic disease and a com- diclofenac-induced hepatic damage uncertain. In our two cases the correlation between the drug and the liver damage is most probable.

Unfortunately in the first case a liver needle biopsy was not performed, but remission after removal of the drug as well as the hypersensitivity type of drug reaction as shown by the skin vasculitis, eosinophilia and histological picture of the bone marrow incriminate diclofenac as responsible for the liver injury. In the second case histological findings in the liver biopsy strongly suggest an allergic drug reaction and the diagnosis is supported by concomitant pruritus, skin rash and eosinophilia.

In conclusion, diclofenac, like other non-steroidal anti-inflammatory drugs, can cause hepatocellular damage. Fortunately, this side effect is very uncommon but nevertheless the diagnosis of drug-induced hepatotoxicity should be considered in patients who develop hepatic damage while receiving the drug.

parative study of diclofenac sodium (Voltarol) with indomethacin in patients with osteroarthritis and rheumatoid arthritis. Rheumatology and Rehabilitation, Suppl. 2, 81 .

MENASSE, R., HEDWALL, P.R., KRAETZ, J. \& PERICIN, C. (1978). Pharmacological properties of diclofenac sodium and its metabolism. Scandinavian Journal of Rheumatology, Suppl. 22, 5.

NASUTION, A.R. (1976). A comparative trial of diclofenac sodium and flufenamic acid in adult patients with extra articular rheumatism. In Voltaren Symposium. p. 53-59. Hans Huber: Bern, Stuttgart, Vienna.

SEAMAN, W.E., ISHAK, K.G. \& PLOTZ, P.H. (1974). Aspirininduced hepatotoxicity in patients with systemic lupus erythematosus. Annals of Internal Medicine, 80, 1.

SHIOKAWA, Y., TOKATORI, M. \& SAKUMA, A. (1972). Multicentre trial of Voltaren (GP 45840) on rheumatoid arthritis by double-blind technique. Journal of the Japanese Rheumatology Association, 12, 271.

TRANG, L., KIRCHHEINER, B. \& WOLLHEIM, F.A. (1976). Diclofenac sodium (Voltaren) in rheumatoid arthritis. A double blind comparison with indomethacin and placebo. In Voltaren Symposium. p.32-39. Hans Huber: Bern, Stuttgart, Vienna.

VICTORINO, R.M.M., SILVEIRA, J.C.B., BAPTISTA, A. \& DEMOURA, M.C. (1980). Jaundice associated with naproxen. Postgraduate Medical Journal, 56, 368.

WHITTAKER, S.J., AMAR, J.H., WANLESS, I.R. \& HEATHCOTE, J. (1982). Sulindac hepatotoxicity. Gut, 23, 875.

ZIMMERMAN, H.G. (1981). Drug induced liver disease: an overview. Seminars on Liver Diseases, 1, 93. 